\title{
PRODUCT LIABILITY: A CHANGING PLAYING FIELD?
}

\author{
Christin Gowar \\ $L L B$ \\ Lecturer, School of Law \\ University of the Witwatersrand, Johannesburg
}

\begin{abstract}
SUMMARY
Product liability in South Africa has historically been classified as falling within the sphere of the law of delict generally; with fault being a necessary element for liability. However, this historical classification has changed with the dawn of a new era in consumer law. The Consumer Protection Act 68 of 2008, and more specifically section 61 , seems to impose liability without fault on certain parties for harm caused by their goods or products. Section 61 , on the face of it, appears to be extremely beneficial for consumers who wish to tackle larger companies and defendants in product liability cases. In practice, though, this may not be the case as section 61 shares a number of similarities with the European Directive on Product Liability of 1985 and the United Kingdom Consumer Protection Act 1987, neither of which has been entirely successful in eliminating fault. This article considers the common-law system which has been applied to product liability cases in the past, and thereafter considers the provisions of the Consumer Protection Act which amend the principles applicable, in order to determine whether section 61 will benefit consumers. The article will further look at how similar provisions in Europe have been interpreted and applied by courts in order to assess the potential problems which might arise from section 61 in South Africa. Once these problems have been identified, this article will address a provision which is unique to the South African statute which may go some way in bringing about a different result in South Africa, thereby avoiding the problems faced in Europe.
\end{abstract}

\section{PRODUCT LIABILITY: THE NEED FOR A SYSTEM OF REDRESS}

Product liability cases in South Africa and abroad have illustrated that there is a wide array of harm which can potentially result from the use of defective products. The harm can range from minor discomfort lasting no longer than a few seconds, to serious injuries of a permanent nature, ${ }^{1}$ to death. Despite this danger, products are a necessity in any society. The activities of designing, manufacturing and distributing products may be said to be central to the wealth and welfare of any society. ${ }^{2}$ In order to incentivize producers and manufacturers to avoid defects in products, and prevent society bearing

\footnotetext{
Wagener \& Cuttings v Pharmacare Ltd 20034 SA 285 (SCA). In this case a defective anaesthetic was used during a shoulder operation which left the patient with paralysis of the right arm and necrosis of the tissue and nerves.

2 Van Eeden A Guide to the Consumer Protection Act (2009) 237.
} 
the cost of the damage, it is essential to hold the producers and/or manufacturers accountable for errors which result in harm. ${ }^{3}$ It is therefore necessary to ensure that a legal system provides its people with an effective system of redress.

Product liability has, in the past, been governed by principles of common law, however, since 1 April 2011, product liability now falls within the legislative framework of the Consumer Protection Act. ${ }^{4}$ The Consumer Protection Act seeks to provide consumers with "an accessible, consistent, harmonised, effective and efficient system of redress".

\section{THE PAST: A FAULT-BASED SYSTEM}

Product liability has, in the past, been regulated mainly by the law of delict, and more specifically the Aquilian action in the South Africa legal system. ${ }^{6}$ The law of delict is responsible for determining the circumstances in which a person, the wrongdoer, is obliged to bear the damage which he or she has caused to another. ${ }^{7}$ The Supreme Court of Appeal, in Ciba-Geigy (Pty) Ltd v Lushof Farms (Pty) $L t d,{ }^{8}$ confirmed that where a manufacturer produces and markets a product which has the potential to be hazardous to consumers, without conclusive prior testing, such negligence may result in the manufacturer being held delictually liable for damages suffered by a consumer. ${ }^{9}$ Under the common-law system, a delictual claim for damages caused by a defective product requires proof of all the elements necessary for delictual liability in order to be successful. These elements are conduct, wrongfulness, fault, causation and damage. Under this system the burden of proving these elements has fallen squarely on the shoulders of the consumer. The elements of wrongfulness and fault require a brief discussion.

\section{Wrongfulness}

It is trite that the test for wrongfulness in the law of delict involves the application of the standard of the "legal convictions of the community" or the

\footnotetext{
Van Eeden 238.

The Consumer Protection Act came into effect on 1 April 2011.

S 3(1) (g) of the Consumer Protection Act.

6 Prior to 1 April 2011. This is where there is no contractual relationship between the parties. Where there is a contract their relationship will be of a contractual nature and the dispute will be regulated by the law of contract. Frequently there is no contract between the parties and in these instances a claim falls under the law of delict. Neethling and Potgieter Neethling-Potgieter-Visser Law of Delict 6ed (2010) 317; Levenstein "Making Things Tougher for Manufacturers" September 2008 Without Prejudice 22 22-23; Levenstein "The New Consumer Protection Act, 2008: Liability of the Manufacturer for Defective Products An Update" February 2010 Legal Brief 1.

$7 \quad$ Neethling and Potgieter 3.

$8 \quad$ Ciba-Geigy (Pty) Ltd v Lushof Farms (Pty) Ltd 20022 SA 447 (SCA) 470.

9 Ciba-Geigy (Pty) Ltd v Lushof Farms (Pty) Ltd supra 470; Unpublished paper by Botha and Joubert "Does the Consumer Protection Act 68 of 2008 Provide for Strict Liability?: A Comparative Analysis" presented at the $1^{\text {st }}$ International Workshop on Trans-border Commercial Law, University of South Africa, Sandton, South Africa, 19-20 October 20095.
} 
boni mores. Applying this test involves a balancing of the interests of the parties and the community in order to assess whether the causing of the damage was a reasonable or unreasonable infringement of the plaintiff's interests or a breach of a legal duty to act positively to prevent the harm suffered by the plaintiff. ${ }^{10}$

Within the framework of product liability, the wrongfulness enquiry focuses on the existence and breach of a legal duty not to cause damage to the consumer. ${ }^{11}$ It has been said that a manufacturer has a duty, in terms of the boni mores, to take reasonable steps to prevent defective products from entering or remaining in the market and infringing the interests of consumers. ${ }^{12}$ The causing of damage by a defective product is in principle wrongful as it is a violation of this legal duty, which was confirmed by the Supreme Court of Appeal in Ciba-Geigy (Pty) Ltd v Lushof Farms (Pty) Ltd. ${ }^{13}$ This means that there must be a defect in the product before wrongfulness on the part of the manufacturer can be established. ${ }^{14}$

In determining whether a product is defective, the feelings, convictions and experience of society need to be considered, and our courts apply the general principles relating to wrongfulness in this regard. ${ }^{15} \mathrm{~A}$ product may be regarded as defective if it is unreasonably dangerous, and it is unreasonably dangerous if it fails to meet the expectations of the reasonable consumer with regards to its safety. ${ }^{16}$ Shortcomings in the design of a product, ${ }^{17}$ as well as insufficient warnings or information being supplied on (or with) products, can be said to be defects. ${ }^{18}$ This being said, inevitably dangerous products, by virtue of their form ${ }^{19}$ or content, ${ }^{20}$ cannot be regarded as defective. $^{21}$

10 Loubser and Ried "Liability for Products in the Consumer Protection Bill 2006: A Comparative Critique" 2006 Stellenbosch Law Review 412 418-419; Van Eeden v Minister of Safety and Security (Women's Legal Centre Trust, as Amicus Curiae) 20031 SA 389 (SCA) par 9; restated in Minister of Safety and Security $v$ Hamilton 20042 SA 216 (SCA) par 16; and see also Minister of Law and Order v Kadir 19951 SA 303 (A) par 7.

11 Herschel v Mrupe 19543 SA 464 (A) 486F; Loubser and Reid 2006 Stellenbosch Law Review 419; Neethling and Potgieter 318; and Loubser (ed), Midgley (ed), Mukheibir, Niesing and Perumal The Law of Delict in South Africa (2009) 244.

12 Van der Merwe and De Jager "Products Liability: A Recent Unreported Case" 1980 SALJ 83 88; and restated, with approval, in Neethling and Potgieter 318.

13 Ciba-Geigy (Pty) Ltd v Lushof Farms (Pty) Ltd supra.

14 Neethling and Potgieter 318; and Loubser et al 244.

15 The question whether a product is defective, according to Neethling and Potgieter, is the crux of the matter for determining product liability under the common-law system; Neethling and Potgieter 318. Loubser and Reid are of the opinion that defectiveness and wrongfulness are linked in that "defectiveness plays a normative and limiting role in determining whether the causing of harm should be considered wrongful". They therefore suggest that defectiveness should be assessed in terms of the legal convictions of the community (or boni mores) and general reasonableness, "as applied to the nature and qualities of the product and in particular its risks and benefits", as in the case of assessing wrongfulness; Loubser and Reid 2006 Stellenbosch Law Review 421; and Loubser et al 244.

16 Neethling and Potgieter 318; and Loubser et al 245

17 The example provided by Neethling and Potgieter (318) is a motor car ashtray designed with a sharp edge which injures a passenger's eye during an emergency stop.

18 Neethling and Potgieter 318.

19 Professors Neethling and Potgieter (318) provide the following examples of such products: a knife, a blade and a saw. 


\section{Fault}

In addition to the presence of wrongfulness, a consumer wishing to claim damages arising from harm caused by a defective product also had to prove fault, at least in the form of negligence, on the part of the manufacturer. ${ }^{22}$ Negligence, being the form of fault encountered most often in cases of product liability, entails testing the conduct of the manufacturer against that of the reasonable person in the same circumstances. ${ }^{23}$ The test for negligence involves two legs: foreseeability and preventability.

Fault on the part of the manufacturer was the most challenging element for consumers to overcome in product liability cases. This requirement was recognised as being the problematic element for a number of reasons, including: $:^{24}$

- ignorance about the production process on the part of the consumer;

- the production process is complicated and inaccessible to consumers; and

- fault is sometimes not present in the production process.

Because of this difficulty some courts started applying the doctrine of res ipsa loquitur ${ }^{25}$ in product liability cases in order to alleviate the burden on consumers. $^{26}$ This doctrine creates two presumptions against the manufacturer, being, first, "the presumption that the manufacturer used an unsuitable production process", and, secondly, that the manufacturer's employees negligently exercised the production process. ${ }^{27}$ These presumptions shift the onus onto the defendant manufacturer ${ }^{28}$ Even though this doctrine could provide assistance to a consumer, the Appellate Division, in Bayer South Africa (Pty) Ltd $v$ Viljoen, ${ }^{29}$ stressed that this doctrine should only be applied in those cases where it was appropriate in view of the facts of the case. The court was in principle not opposed to applying the doctrine

20 Professors Neethling and Potgieter (318) provide the following examples of defects in the content: cigarettes and alcohol.

21 Neethling and Potgieter 318.

22 Van der Merwe and De Jager 1980 SALJ 90. Here it is important to note that it is not only the manufacturer who may be at fault; McQuoid-Mason "Consumer Law: The Need for Reform" 1989 THRHR 32 35. The seller of the product may also be at fault, and in such cases "the negligence issue involves the question of whether, in the circumstances of the case, [the seller] had a duty to inspect the product before the sale". Loubser et al 246.

23 Neethling and Potgieter 318; Wagener \& Cuttings v Pharmacare Ltd supra; and Ciba-Geigy (Pty) Ltd v Lushof Farms (Pty) Ltd supra.

24 Neethling and Potgieter 319; Van der Merwe and De Jager 1980 SALJ 91; McQuoid-Mason 1989 THRHR 35; Botha and Joubert Unpublished Paper 9; Levenstein September 2008 Without Prejudice 23; Levenstein 2010 Legal Brief 1; and Wagener \& Cuttings v Pharmacare Ltd supra par 10.

25 Res ipsa loquitur means that the facts speak for themselves. When this doctrine is applied an inference of negligence can be drawn from the harmful circumstances which result, if the event(s) would not have taken place had someone not been negligent.

26 Davids "The Protection of Consumers" 1966 SALJ 87 94; and Neethling and Potgieter 319.

$27 \quad$ Neethling and Potgieter 319.

28 Ibid.

29 Bayer (South Africa) (Pty) Ltd v Viljoen 19902 SA 647 (A). 
of res ipsa loquitur where policy considerations justified its application, however, Milne JA wanted to restrict the doctrine to its "normal" application, that is, where the facts of the case give rise to an inference of negligence.

Under the common-law system consumers were often faced with the sometimes impossible task of having to prove fault in order to be successful. As such, there have been a number of arguments put forward in favour of the imposition of strict liability, or as it is also termed, liability without fault. "Strict liability is a legal doctrine that makes some persons responsible for damages their actions or products cause, regardless of any 'fault' on their part." ${ }^{\prime 30}$ In Wagener \& Cuttings $v$ Pharmacare $L t d^{31}$ the Supreme Court of Appeal was called on to impose strict liability on manufacturers where their defective products caused harm. The Supreme Court of Appeal, after a consideration of all the arguments in favour of and against the imposition strict liability, declined the invitation and confirmed fault as a requirement for delictual liability in product liability cases. The Supreme Court of Appeal reached the conclusion that the imposition of strict liability in product liability cases was to be imposed by the legislature, and not by the courts, if it were to be imposed at all. ${ }^{32}$

Therefore, under the common-law system consumers were provided with a remedy with which to seek redress, however, due to practical problems consumers faced when applying the remedy in practice, justice was not always achieved. The Consumer Protection Act seeks to remedy these problems by providing an effective and efficient system of redress for consumers.

\section{THE FUTURE: SECTION 61 OF THE CONSUMER PROTECTION ACT}

The Consumer Protection Act has brought change to the product liability regime in South Africa. The purpose of the Consumer Protection Act, and more specifically section 61 , is to make it easier for consumers to hold manufacturers and other parties in the supply chain responsible for damage caused by their goods. ${ }^{33}$ Section 61 of the Consumer Protection Act, which regulates liability for damage caused by goods, appears to answer the call for the introduction of strict liability and appears to broaden the scope of liability in the interests of consumers. ${ }^{34}$

\footnotetext{
30 Botha and Joubert Unpublished Paper 3; quoting from "Free Advice" http://law. freeadvice.com/general_practice/legal_remedies/strict_liability.htm accessed 2009-07-29. There has only been one instance in the past in which the court imposed strict liability. This was for consequential damage which arose from hidden defects in products which caused harm where the seller or retailer professed skill and expert knowledge in relation to the product; Kroonstad Westelike Boere Ko-op Vereeniging v Botha 19643 SA 561 (A) 571; and McQuoid-Mason 1989 THRHR 35.

31 Wagener \& Cuttings $v$ Pharmacare Ltd supra.

32 Wagener \& Cuttings v Pharmacare Ltd supra par 29-30.

33 Levenstein September 2008 Without Prejudice 22.

34 Botha and Joubert Unpublished Paper 8.
} 


\section{General Provisions of the Consumer Protection Act}

The preamble to the Consumer Protection Act emphasises the need to protect the interests of all consumers, and the need to "ensure accessible, transparent and efficient redress for consumers who are subjected to abuse or exploitation in the marketplace". The preamble to the Consumer Protection Act also states that the purpose of the enactment is to provide protection from hazards to the well-being and safety of consumers, as well as to develop a system of redress which is effective for consumers.

The Consumer Protection Act applies to every transaction which occurs within the Republic of South Africa, unless exempt by section 5(2) or 5(3) and (4). ${ }^{35}$ A "transaction" under the Consumer Protection Act includes an agreement for the supply or potential supply of goods or services in exchange for consideration; or supplying goods for consideration to or at the direction of a consumer; or performing a service for consideration for or at the direction of a consumer. ${ }^{36}$ However, even if a transaction is exempt from the provisions of the Consumer Protection Act, all transactions are subject to the provisions of section $61 .{ }^{37} \mathrm{~A}$ consumer would therefore still be entitled to rely on the provisions of section 61 in order to hold a producer, importer, distributor or retailer liable for damage arising from a defective product if the transaction is exempted by either section 5(2) or sections 5(3) and (4).

The Consumer Protection Act further applies to: ${ }^{38}$

“...

(b) the promotion of any goods or services, or of the supplier of any goods or services, within the Republic, unless -

(i) those goods or services could not reasonably be the subject of a transaction to which [the Consumer Protection Act] applies ...; or

(ii) the promotion of those goods or services has been exempted in terms of [section 5(3) and (4)];

(c) goods or services that are supplied or performed in terms of a transaction to which [the Consumer Protection Act] applies, irrespective of whether any of those goods or services are offered or supplied in conjunction with any other goods or services, or separate from any other goods or services; and

(d) goods that are supplied in terms of a transaction that is exempt from the application of [the Consumer Protection Act], but only to the extent provided for in [section 5(5)]."

35 S 5(1)(a) of the Consumer Protection Act; and $s$ 5(3) and (4) deal with industry-wide exemptions which may be granted by the Minister. A regulatory authority may apply to the Minister, in terms of s 5(3), for an industry-wide exemption from one or more of the provisions contained in the Consumer Protection Act, on the ground that those provisions overlap or duplicate a regulatory scheme administered by that regulatory authority in terms of any national legislation, or any treaty, international law, convention or protocol.

36 S 1 of the Consumer Protection Act; Du Preez "The Consumer Protection Bill: A Few Preliminary Comments" 2009 TSAR 5867.

37 S 5(5) of the Consumer Protection Act.

$38 \mathrm{~S} 5(1)$ of the Consumer Protection Act. 
"Goods", as defined in section 1 of the Consumer Protection Act, include:

"(a)anything marketed for human consumption;

(b) any tangible object not otherwise contemplated in paragraph (a), including any medium on which anything is or may be written or encoded;

(c) any literature, music, photograph, motion picture, game, information, data, software, code or other intangible product written or encoded on any medium, or a licence to use any such intangible product;

(d) a legal interest in land or any other immovable property, other than an interest that falls within the definition of 'service' in this section; and

(e) gas, water and electricity".

"Consumer" includes not only those persons to whom goods or services are marketed or persons who have entered into transactions with suppliers, but also users of goods and beneficiaries and recipients of services. ${ }^{39}$ Therefore, it is not only contracting parties who are protected; those who did not buy the product can still benefit. ${ }^{40}$ Consumers are furthermore not limited to South African citizens. ${ }^{41}$

\section{Section 61}

Section 61(1) of the Consumer Protection Act provides as follows:

"Except to the extent contemplated in subsection (4), the producer or importer, distributor or retailer of any goods is liable for any harm, as described in subsection (5), caused wholly or partly as a consequence of -

(a) supplying any unsafe goods;

(b) a product failure, defect or hazard in any goods; or

(c) inadequate instructions or warnings provided to the consumer pertaining to any hazard arising from or associated with the use of any goods, irrespective of whether the harm resulted from any negligence on the part of the producer, importer, distributor or retailer, as the case may be".

A "producer" is defined in section 1 of the Act as:

"a person who -

(a) grows, nurtures, harvests, mines, generates, refines, creates, manufactures or otherwise produces the goods within the Republic, or causes any of those things to be done, with the intention of making them available for supply in the ordinary course of business; or

(b) by applying a personal or business name, trade mark, trade description or other visual representation on or in relation to the goods, has created or established a reasonable expectation that the person is a person contemplated in paragraph (a)".

"Importer", with respect to any goods, is defined as meaning "a person who brings those goods, or causes them to be brought, from outside the Republic into the Republic, with the intention of making them available for

39 Definition of "consumer" as set out in s 1 of the Consumer Protection Act.

40 S 1 of the Consumer Protection Act; Loubser et al 247; Du Preez 2009 TSAR 68; and Maphosa “If You Didn't Buy It, You Still Benefit" November 2008 Without Prejudice 55.

41 S 1 of the Consumer Protection Act; and Du Preez 2009 TSAR 68. 
supply in the ordinary course of business" ${ }^{42}$ A "distributor" is a person who is supplied in the ordinary course of business with goods by a producer, an importer or a distributor and supplies those goods to another distributor or to a retailer. ${ }^{43} \mathrm{~A}$ person who supplies goods to a consumer in the ordinary course of business is a "retailer". ${ }^{44}$

In order to amount to a defect for the purposes of section 61(1), there must be proof, in terms of section 53(1), of a "material imperfection in the manufacture of the goods or components, or in performance of the services, that renders the goods or results ... less acceptable than persons generally would be reasonably entitled to expect in the circumstances"; or there must be proof that any characteristic of the goods or components renders the goods or components less useful or safe than persons generally would be reasonably entitled to expect in the circumstances. ${ }^{45}$ A "failure" is described as "the inability of the goods to perform in the intended manner or to the intended effect". ${ }^{46}$ A "hazard" is a characteristic of the goods which has been identified or declared by any law to be a hazard, or it is a characteristic of the goods which, when the goods are used, poses a significant risk of injury to any person or damage to property. Finally, "unsafe" refers to goods which "present an extreme risk of personal injury or property damage to the consumer or other persons".

Under section 61(5), such a producer, importer, distributor or retailer may be held liable without fault for any death, injury or illness caused to a natural person, damage to or loss of property (whether movable or immovable), and economic loss which may result from this harm. ${ }^{48}$ Any claim for pain and suffering, loss of amenities of life, or other non-patrimonial damage will still be required to be brought under the law of delict and fault will be a requirement. The Consumer Protection Act makes no provision for consideration of contributory negligence on the part of consumers or others.

A number of defences are set out in section 61(4) of the Consumer Protection Act. A defendant will not incur liability if the unsafe product characteristic, failure, defect or hazard is attributable to compliance with public regulation. ${ }^{49}$ Liability does not arise if the "alleged unsafe product characteristic, failure, defect or hazard did not exist in the goods at the time that the goods were supplied by that person to another person alleged to be liable" ${ }^{50}$ If it is unreasonable, when one has regard to the person's role in marketing the goods, to expect the distributor or retailer to have discovered the unsafe product characteristic, failure, defect or hazard, the liability without fault regime is also excluded. ${ }^{51}$ This last-mentioned defence is

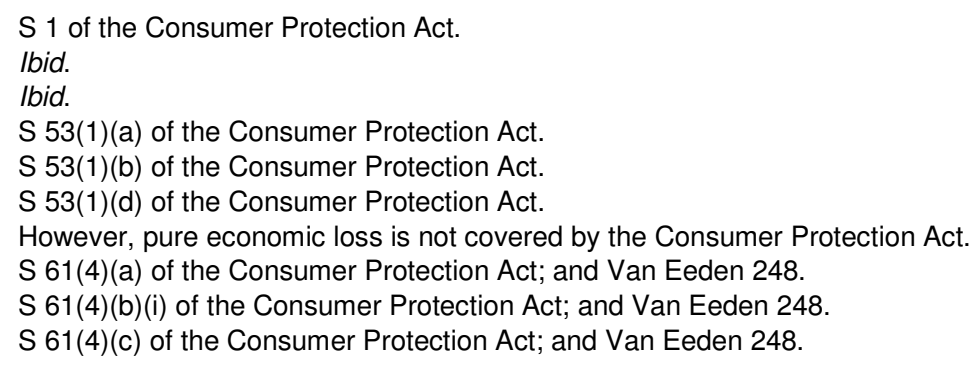


specifically aimed at the distributor or other person who only plays a limited role in the distribution of the product to consumers. ${ }^{52} \mathrm{~A}$ further defence based on prescription is set out in sections 61(4)(d)(i) to (iv) of the Consumer Protection Act.

Although section 61 of the Consumer Protection Act does not refer to "consumers" as such, Professors Neethling and Potgieter argue that, because the Consumer Protection Act is aimed at protecting consumers only, it is likely that only consumers will be afforded the protection of section 61 and innocent bystanders who are not users, beneficiaries or recipients, who are injured by a defective product will still need to rely on the ordinary delictual principles of common law. ${ }^{53}$ It thus appears, on the face of it, that section 61 is going to be highly beneficial to consumers who suffer harm as a result of defective goods. It appears that consumers will no longer be required to prove fault on the part of the manufacturer or producer in order to hold them liable. The next section however casts a shadow of doubt on the actual benefit which will arise in practice, despite the theory.

\section{WHAT THE FUTURE HOLDS: A SURVEY OF SIMILAR PROVISIONS IN EUROPE}

Section 61 largely resembles the provisions of the European Union Directive on Product Liability of $1985,{ }^{54}$ and certain provisions of the United Kingdom Consumer Protection Act of $1987 . .^{55}$ In terms of section 2(2)(a) of the Consumer Protection Act our courts may, when interpreting or applying the Consumer Protection Act, consider appropriate foreign and international law. Therefore, it is necessary to consider the similar provisions in these foreign instruments briefly, and the interpretations adopted by foreign courts, in order to determine the potential outcomes which may be adopted by South African courts.

\section{European Directive on Product Liability of 1985}

The European Directive on Product Liability was the result of divergences which existed in the laws of member states and had the effect of potentially distorting competition and affecting the movement of goods within the common market. The Directive indicates that the only way in which this problem could be overcome was through the introduction of liability without the need to prove fault. ${ }^{56}$ The Directive is an instruction which is given to member states and is binding by virtue of the Treaty of Rome, and requires

\footnotetext{
Van Eeden 248

Neethling and Potgieter 374.

Council Directive 85/374/EEC of 25 July 1985.

55 Loubser et al 248; Loubser and Reid 2006 Stellenbosch Law Review 424; and Van Eeden 245.

56 Preamble to the European Directive on Product Liability of 1985.
} 
European Union member states to implement domestic legislation giving effect to its provisions within a certain time period. ${ }^{57}$

In terms of Article $1 \mathrm{a}$ "producer shall be liable for damage caused by a defect in his product". A "product" includes "all movables even if incorporated into another movable or an immovable". ${ }^{58}$ The consumer who is injured by the defective product is required to prove the damage, the defect, as well as causation. ${ }^{59}$ A product is regarded as defective, in terms of the Directive, if it fails to provide the safety which a consumer is entitled to expect. All circumstances are to be taken into consideration when determining the safety one can expect, including "(a) the presentation of the product; (b) the use to which it could reasonably be expected that the product would be put; [and] (c) the time when the product was put into circulation" ${ }^{60}$

The Directive sets out a number of defences which a producer can raise against a claim for damages resulting from a defective product, including the defence that the producer was not able to discover the existence of the defect at the time the product was put into circulation due to the state of scientific and technical knowledge. ${ }^{61}$ The producer shall be liable for damage which is caused by death or personal injury, as well as for "damage to, or destruction of, any item of property other than the defective product itself, with a lower threshold of $500 \mathrm{ECU}$, provided that the item of property (i) is of a type ordinarily intended for private use or consumption; and (ii) was used by the injured person mainly for his own private use or consumption". ${ }^{62}$

\section{United Kingdom Consumer Protection Act 1987}

This legislation was adopted in order to give effect to the provisions of the European Directive on Product Liability in the United Kingdom. Part 1 of the United Kingdom legislation deals with product liability. In terms of sections 2(1) and (2) the producer, a person who puts his name or mark on the product, or a person who has imported the product, shall be liable for any damage which is caused wholly or partly by a defect in that product. A supplier of the product can also be held liable for any such damage if the person who was harmed requests the supplier to identify the producer, the person who attached their name or mark, or the person who imported the product, and the supplier then fails to provide this information within a reasonable time, provided that the request was made within a reasonable time after the harm had occurred and it was not reasonably practicable for the harmed person to identify those persons. ${ }^{63}$

\footnotetext{
Stapleton "Restatement (Third) of Torts: Products Liability, An Anglo-Australian Perspective" 2000 Washburn Law Journal 363370.

8 Article 2 of the European Directive on Product Liability of 1985.

Article 4 of the European Directive on Product Liability of 1985.

Article 6 of the European Directive on Product Liability of 1985

Article 7 of the European Directive on Product Liability of 1985

Article 9 of the European Directive on Product Liability of 1985

63 S 2(3) of the United Kingdom Consumer Protection Act 1987.
} 
A product is said to contain a defect if "the safety of the product is not such as persons generally are entitled to expect" and "safety", in relation to such products, includes "safety with respect to products comprised in that product and safety in the context of risk of damage to property, as well as in the context of risks of death or personal injury" ${ }^{64}$ When one has to determine what persons are generally entitled to expect in relation to a product, one has to take into account all the circumstances, which include "the manner in which, and purposes for which, the product has been marketed, its get-up, the use of any mark in relation to the product and any instructions for, or warnings with respect to, doing or refraining from doing anything with or in relation to the product; what might reasonably be expected to be done with or in relation to the product; and the time when the product was supplied by its producer to another". ${ }^{65}$

The United Kingdom legislation sets out a number of defences which can be raised against a product liability claim, such as showing that the defect can be attributed to having to comply with any requirement imposed by an enactment or any community obligation; that the defendant being sued did not supply the product to another person at any time; that the product was free from any defects at the relevant time; and that "the state of scientific and technical knowledge at the relevant time was not such that a producer of products of the same description as the product in question might be expected to have discovered the defect if it had existed in his products while they were under his control". ${ }^{66}$ The harm for which a defendant can be held liable includes death, personal injury, and loss of or damage to property, but a defendant may not be held liable for any damage to the product itself. ${ }^{67}$

\section{Approach adopted by the courts in foreign jurisdictions}

In those European countries which have similar product liability provisions to the Consumer Protection Act, a number of interpretations and approaches have emanated from court decisions which, when one considers them, shed doubt on the ability of section 61 of the Consumer Protection Act to impose strict liability in practice. These approaches adopted by foreign courts have been dealt with comprehensively by other academic authors and will be summarised briefly below.

S 3(1) of the United Kingdom Consumer Protection Act 1987.

S 3(2)(a)-(c) of the United Kingdom Consumer Protection Act 1987.

S 4 of the United Kingdom Consumer Protection Act 1987.

67 S 5(1) and (2) of the United Kingdom Consumer Protection Act 1987. However, in terms of s 5(4) the amount which can be awarded for damage to private property may not exceed the amount of £275. The Act does not impose any financial limit on a producer's total liability. See also the Consumer Affairs Directorate Guide to the Consumer Protection Act 1987: Product Liability and Safety Provisions http://www.bis.gov.uk/files/file22866.pdf accessed 2011-01-10. 


\section{Consumer expectations test}

Liability is triggered under section 61(1)(b) of the Consumer Protection Act, where the harm results from a product failure, defect or hazard in the goods. As mentioned previously, a defect, for purposes of section 61(1) of the Consumer Protection Act means "any material imperfection in the manufacture of the goods or components, or in performance of the services, that renders the goods or results ... less acceptable than persons generally would be reasonably entitled to expect in the circumstances"; or there must be proof that any characteristic of the goods or components renders the goods or components less useful or safe than persons generally would be reasonably entitled to expect in the circumstances. ${ }^{68}$ This test is sometimes referred to as the "consumer expectations" test. The South African Consumer Protection Act is not the first statute to introduce such a test. The consumer expectations test was also incorporated in the European Directive on Product Liability and the United Kingdom Consumer Protection Act. ${ }^{69}$ The consumer expectations test has, however, not been entirely satisfactory in Europe and has resulted in the language of strict liability contained in the provisions not being followed through in factual scenarios. ${ }^{70}$

This test has been highly criticised by authors in the United Kingdom. According to authors Prosser and Keeton the meaning of the test is ambiguous and, because it is such a vague concept, it does not provide much guidance for the courts in many situations. ${ }^{71}$ On the one hand, the reasonable consumer cannot expect to be adversely affected by risks or hazards which are unknown to the consumer, but, on the other hand, a reasonable consumer would contemplate the possibility of unknown side effects resulting. ${ }^{72}$ They argue that a reasonable consumer can expect no more than the exercise of reasonable skill and knowledge. ${ }^{73}$

This test purports to be an objective, normative standard for determining the defectiveness of goods, however courts appear, in practice, to conduct an "objective enquiry into the attributes, risks and benefits of a product". ${ }^{74}$ The application of the consumer expectations test thus ultimately involves a value judgment. ${ }^{75}$ Commentary on the European Directive has indicated that the language of strict liability is not followed through. ${ }^{76}$ It has been said that this test is too vague to provide much guidance and it may be manipulated by courts to explain or justify almost any result which the court chooses to reach. ${ }^{77}$ The test also cannot be said to mean that courts must somehow

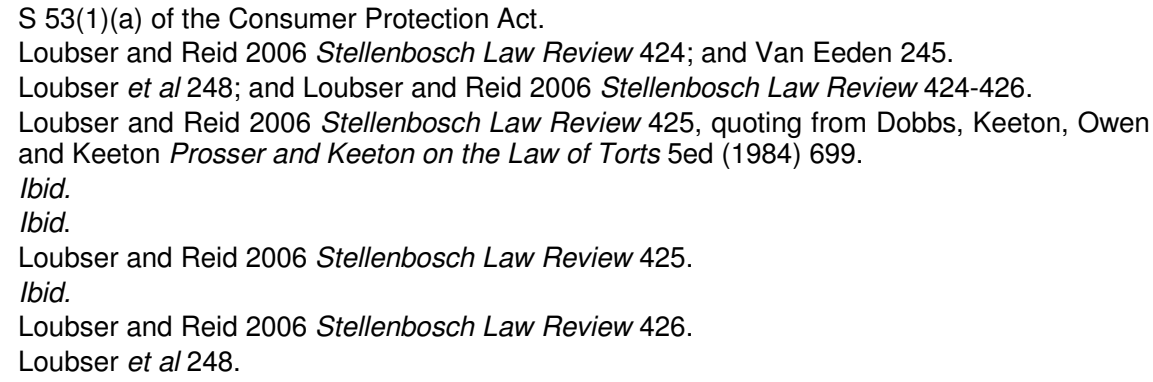


determine the actual expectations of consumers generally as a legal norm cannot fairly and coherently be based on such a volatile standard. ${ }^{78}$ Some people harbour the absurd belief that nothing can or will go wrong in their lives, and people also sometimes misjudge the risks involved. ${ }^{79}$

Even if one were to accept that the consumer expectations test did mean that our courts should in fact determine what consumers are entitled to expect, the test is still inadequate because, as a normative concept, it cannot be rationalised. ${ }^{80} \mathrm{~A}$ consumer can simply say that in his or her opinion, the design did not meet consumer expectations. ${ }^{81}$ It has further been suggested by some authors that this problem has been "compounded in the South African [Consumer Protection Act], because the definition of 'defect' employs a number of other undefined terms that are open-ended and vague, such as 'acceptable', 'useful', and 'practicable'”. 82

This emphasis on what the consumer is "entitled" to expect, as opposed to the actual expectations, leads our courts "back to a standard of reasonableness and the extent to which the conduct of the relevant person meets reasonable expectations is often considered relevant", say Professor Max Loubser and Elspeth Reid. ${ }^{83}$ In assessing this, the courts often consider factors such as costs of improving the safety of the product and any consequent loss in utility, which factors draw one back to the test for negligence.$^{84}$ The definition of defect in the Consumer Protection Act, as well as the standard to be employed, fails in the essential task of providing a standard which can work in practice for the determining of the defectiveness of a product. ${ }^{85}$

Despite the implementation of strict liability in the European Union Directive and the United Kingdom Consumer Protection Act, none of these instruments has entirely eliminated elements of a fault-based system. Given that the same test has been incorporated into the South African law, the question arises whether strict liability will really be imposed in this country when a plaintiff relies on section 61(1)(b) of the Consumer Protection Act. This is a real concern given that our courts may, in terms of section 2 of the Consumer Protection Act, consider appropriate foreign and international law when interpreting and applying the Consumer Protection Act.

78 Ibid.

79 Stapleton 2000 Washburn Law Journal 376; and Loubser and Reid 2006 Stellenbosch Law Review 426.

80 Loubser and Reid 2006 Stellenbosch Law Review 426; and Loubser et al 248.

81 Ibid.

82 Loubser et al 248.

Loubser and Reid 2006 Stellenbosch Law Review 427.

84 Ibid.

85 Loubser and Reid 2006 Stellenbosch Law Review 428. Van Eeden disagrees with the criticism levelled against the consumer expectations test. Van Eeden recognises the argument put forward by Loubser and Reid regarding the consumer expectations test and the focus on what consumers are "entitled" to expect as opposed to actual expectations. However, Van Eeden submits that while this suggestion by these authors has considerable merit, "the test as formulated has the benefits of constituting a standard incorporating language not specifically used in the determination of negligence, and of being more closely related to language employed in existing international instruments". Van Eeden 245. 


\section{Development risk defence}

A further issue which casts doubt on the liability-without-fault regime introduced by section 61(1) is the defence provided to a distributor or retailer in terms of section 61(4)(c) of the Consumer Protection Act. In terms of this defence liability does not arise "if it is unreasonable to expect the distributor or retailer to have discovered the unsafe product characteristic, failure, defect or hazard, having regard to that person's role in marketing the goods to consumers". ${ }^{86}$ This defence is similar to that contained in the European Directive and the United Kingdom Consumer Protection Act in that one is required to determine the reasonableness of the defendant's conduct in regard to certain circumstances. In Europe one has to consider the "state of scientific and technical knowledge" at the time and this has come to be known as the "development risk defence".

This defence has been said to be one of the most controversial features of the Directive, as it may be regarded as readmitting fault-based liability into product liability cases. ${ }^{87}$ It is said to allow a defendant to escape liability without fault by showing that it was not at fault with regard to establishing latent risk. ${ }^{88}$ This defence provided in the Consumer Protection Act appears to open a significant gap in the "strict liability" framework for those distributors and retailers who can persuade the court that they acted reasonably, given their role in the marketing of the product.

This section may provide a retailer or distributor with a way of escaping liability in the absence of negligence and foreseeable risk, should our courts follow the European interpretation. This defence may therefore circumvent the regime introduced in section $61(1)$ by allowing liability to actually only result in those instances where the defendant was at fault. The only real advantage to the consumer is that the defendant will in future have to bear the onus of proving that he/she acted reasonably, and not negligently. The "development-risk" defence reduces the liability of retailers and distributors of goods to something no broader than negligence liability.

Ultimately, this defence provided in section 61 appears to place the consumer in a worse position than they would have been under the common-law system when it comes to sellers who are experts. Under the common-law system a consumer could hold a seller who professed skill and expert knowledge in the product liable without fault. ${ }^{89}$ This defence will, however, provide such a seller with a defence, thereby depriving the consumer of the advantage afforded by the common-law system. ${ }^{90}$

$86 \mathrm{~S} 61(4)(\mathrm{c})$ of the Consumer Protection Act. It must be pointed out that producers and importers are specifically excluded from the application of this defence. It therefore only offers exemption from liability to distributors and retailers.

87 Loubser and Reid 2006 Stellenbosch Law Review 446.

88 Ibid, considering the argument put forward by Stapleton and others.

89 Kroonstad Westelike Boere Ko-op Vereeniging v Botha supra.

90 Although $s$ 2(10) of the Consumer Protection Act provides that "[n]o provision of [the Consumer Protection Act] must be interpreted so as to preclude a consumer from exercising any rights afforded in terms of the common law", the common law protection provided to consumers dealing with expert sellers is in direct conflict with the $s 61(4)(c)$ 


\section{A fault-based system in disguise?}

After reading the above sections one can see that it is uncertain whether our courts will ultimately interpret the provisions of section 61(1)(b) of the Consumer Protection Act in such a way as to impose strict liability on manufacturers and producers, given European interpretations. Furthermore, a defendant who is a retailer or distributor may raise a no-negligence defence should our courts follow the foreign interpretations, thereby allowing nothing more than liability only in those instances where the defendant was at fault. Consumers may in future have the "benefit" of section 61 in theory, without any benefits actually occurring in practice, with fault being allowed into the system through the back door. However, despite the similarities between the Consumer Protection Act and other instruments discussed, there may be hope emanating from a provision unique to the South African Consumer Protection Act.

\section{POTENTIAL FOR SOUTH AFRICA TO BE DIFFERENT?}

Despite the same apparently problematic tests finding their way into the Consumer Protection Act, there is one important difference between the South African Act and its counterparts in other jurisdictions. Section 2(1) of the Consumer Protection Act specifically sets out that the Act and all its provisions are to be interpreted in a manner that gives effect to the purposes of the Consumer Protection Act. ${ }^{91}$ Our courts are instructed to adopt a purposive method of interpretation. A "purposive method of interpretation" means that the legislative provision in question is to be afforded a meaning in light of the purpose the legislation seeks to achieve in the context of the statute it forms part of ${ }^{92}$ The purposive interpretation does not centre on the intention of the legislature and does not focus exclusively on the literal meaning of the words. ${ }^{93}$ Rather the focal point of such an interpretation is the purpose or object of the statute, which is very real. ${ }^{94}$ Such a purposive method of interpretation is likely to lead to a different outcome than would otherwise have been expected if the traditional rules of interpretation were to be employed. ${ }^{95}$

defence provided to retailers by the Consumer Protection Act. It therefore remains to be seen whether our courts will continue to recognize this common law protection for consumers in spite of s 61(4)(c) of the Consumer Protection Act. The possibility remains that consumers may be worse off under the Act.

91 This provision was not contained in the Consumer Protection Bill. A number of the authors who have discussed the foreign courts' approaches based their criticism on the Bill and therefore would not have been aware of this provision which was ultimately included in the Consumer Protection Act.

92 Du Plessis Re-Interpretation of Statutes (2002) 96.

93 Devenish Interpretation of Statutes (1992) 35.

94 Devenish 36.

95 Du Preez 2009 TSAR 66. 
Section 3 sets out the purposes of the Consumer Protection Act, all of which place emphasis on the protection of consumers. Section $3(1)(h)$ specifically provides that the "purposes of this Act are to promote and advance the social and economic welfare of consumers in South Africa by providing for an accessible, consistent, harmonised, effective and efficient system of redress for consumers". Section 4(2) also specifically instructs the court to develop the common law as is necessary in order to improve the realization and enjoyment of consumer rights, and to promote the spirit and purpose of the Act and appropriate orders to give practical effect to the consumer's right of access to redress.

In practice, this may mean that the Consumer Protection Act, in most cases, if not all, will be interpreted to benefit the consumer as opposed to the producer, importer, distributor or retailer. ${ }^{96}$ The imposition of liability without fault would place consumers in the best position possible, and one can only hope that our courts will bear this purpose in mind at all times when determining liability in terms of section 61 . Maybe this provision will be the difference between the Consumer Protection Act and its counterparts in other jurisdictions, resulting in strict liability in South Africa. Perhaps the Consumer Protection Act does have what it takes to allow our courts to interpret these provisions in a novel and unique way.

\section{CONCLUSION}

The Consumer Protection Act changes the playing field in the sphere of product liability. Plaintiffs under the previous common-law system sought assistance from the law of delict and were required to conquer often insurmountable challenges. Under the Consumer Protection Act consumers are able to claim damages under section 61. At first glance the Consumer Protection Act appears to impose strict liability and broaden the scope of liability to be imposed in product liability cases. However, a closer analysis of the European product liability system shows that the same tests have not had the desired effect in that area, which raises the question as to whether section 61 will ultimately benefit consumers in South Africa.

Despite some apparently vague and problematic tests finding their way into the South African Consumer Protection Act, our statute is unique in that it instructs courts, in all instances, to adopt a purposive method of interpretation. This provision may be the ultimate saviour in preventing South Africa from following foreign interpretations and allowing fault back into product liability cases. In order to place the consumer in the best position possible, our courts will need to interpret section 61 in such a way as to impose liability without fault, without allowing any remnants of the old system back in. One can only hope that our courts will heed to this purposive method of interpretation and protect consumers to the fullest extent. 